\title{
First record of Parnassius apollo (Linnaeus, 1758) (Lepidoptera: Papilionidae) from Chatkal Range, West Tian-Shan
}

\section{Первая находка Parnassius apollo (Linnaeus, 1758) в Чаткальском хребте (Западный Тянь-Шань) (Lepidoptera: Papilionidae)}

\author{
S.K. Korb \\ C.K. Корб
}

Russian Entomological Society, Nizhny Novgorod Division, P.O. Box 97, Nizhny Novgorod 603009 Russia. E-mail: stanislavkorb@1ist.ru.

Русское Энтомологическое Общество, Нижегородское отделение, а/я 97, Нижний Новгород 603009 Россия.

Keywords: Apollo Butterfly, protected species, new distribution data, Kyrgyzstan.

Ключевые слова: Аполлон, охраняемый вид, новые данные по распространению, Киргизия.

Abstract. Parnassius apollo (Linnaeus, 1758), collected from near Avletim village in the Chatkal Mountain Range, West Tian-Shan, is new to West Tian-Shan.

Резюме. Parnassius apollo (Linnaeus, 1758) впервые приводится из Чаткальского хребта (долина р. Авлетим близ пос. Авлетим). Это первая достоверная находка данного вида на Западном Тянь-Шане.

Parnassius apollo (Linnaeus, 1758) (Apollo Butterfly) is an endangered species; in Kyrgyzstan it confirmed from only North Tian-Shan (mountain ridges Kirghizsky, Terskey Ala-Too, Kungey Ala-Too and Ketmen) [Korb, 2013]. From West Tian-Shan it was known by two old and unclear records: «Ferghana», «westlichen Teil des Tianschan» [Stichel, 1907: 25, 36], «W. Thianschan» [Bollow, 1929: 49]; not even one exact locality was given and no records in the last 100 years are known. In fact, the second record [Bollow, 1929] is an iteration of the first one in a new edition of the same book. Thus this species was indicated in West Tian-Shan by Tshikolovets [2005: 91] in Talass Alatoo Mts. with remark «Distribution in Talass Alatoo... requires clarification».

In the beginning of August 2021 a population of this species found in Chatkal Range near the village Avletim. Due to its status (restricted for collecting; the species is in the CITES list and in the IUCN Red Data Book) [IUCN, 2021], the species only photographed but not collected. In its locality it is not rare.

The species recorded visually and photographed.

\section{Results}

Parnassius apollo(Linnaeus, 1758)

Fig. 1.

Material. Kyrgyzstan: Dzhalal-Abad Province, Chatkal

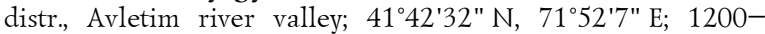
1500 m; 8.VIII.2021; obs. Gamal Soronkulov; photographed in nature.

\section{Discussion}

According $P$. apollo distribution described by Tshikolovets [2005: 91, map], two unconfirmed localities in West Tian-Shan are known. One of them is AksuDzhabagly Nature Reserve in Kazakhstan, and the distance between this locality and the new one is at least $120 \mathrm{~km}$. The second old unconfirmed locality is in Talass Alatoo Mts. northwards of Toktogul reservoir and the distance between the new locality and the old one is also about $120 \mathrm{~km}$.

The closely located confirmed localities are in the northern slope of Kirghizsky Mts. near Kara-Balta town; the distance between new locality and the closest confirmed one is about $250 \mathrm{~km}$.

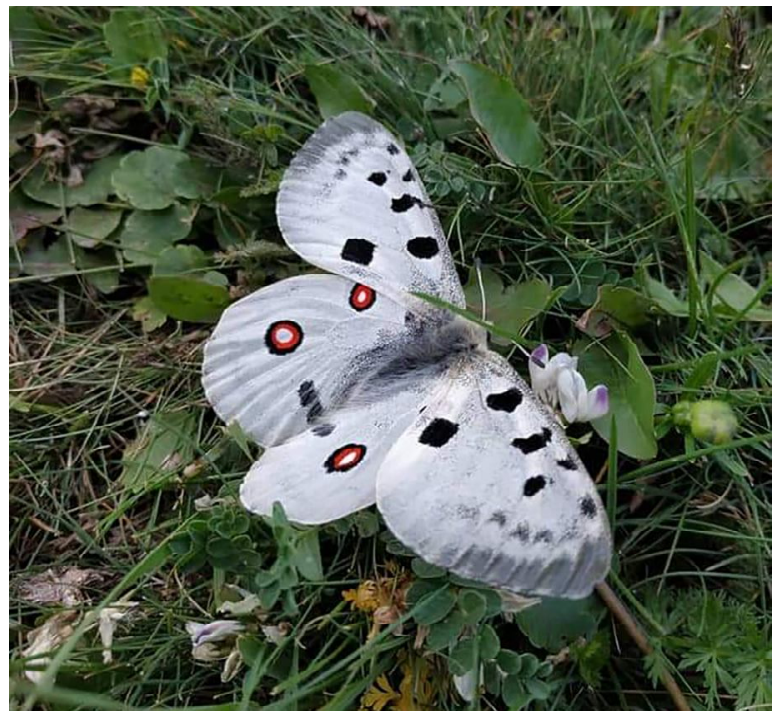

Fig. 1. Parnassius apollo (Linnaeus, 1758). 8.08.2021, Avletim valley near Avletim village, Chatkal Ridge. Photo by: Gamal Soronkulov.

Рис. 1. Parnassius apollo (Linnaeus, 1758). 8.08.2021, Авлетимская долина, окр. А. Авлетим, Чаткальский хребет. Фото Гамаля Соронкулова. 
The probable reason that this species was not found on the territory of West Tian-Shan is its biology. Apollo butterfly lives in the middle mountains, usually up to $2200 \mathrm{~m}$; moreover, this species is local. Most of the lepidopterological expeditions that worked in the West Tian-Shan visited high-mountain passes (above 2500 $\mathrm{m}$ ) or places where this species cannot occur (arid localities of Ala-Buka, Kara-Buura, Chatkal, etc.).

\section{Acknowledgements}

Author is very thankful to Mr Gamal Soronkulov (Talas, Kyrgyzstan) who provided the photo of the specimen and locality data.

\section{References}

Bollow C. 1929. Parnassius // Seitz A. (Ed.). Die Grossschmetterlinge der Erde. Die Palaearktischen Tagfalter. Supplement. Stuttgart: Alfred Kernen Verlag. Bd.1. P.20-83.

IUCN 2021. The IUCN Red List of Threatened Species. Version 2021-1. https://www.iucnredlist.org. Downloaded on [14.08.2021].

Korb S.K. 2013. The butterflies of North Tian-Shan (Lepidoptera: Papilionoformes). Part I. Hesperiidae, Papilionidae, Pieridae, Satyridae // Eversmannia. Suppl.3. 84 p. [In Russian].

Stichel H. 1907. Parnassius // Seitz A. (Ed.): Die Grossschmetterlinge der Erde. Die Palaearktischen Tagfalter. Stuttgart: Alfred Kernen Verlag. Bd.1. P.19-36.

Tshikolovets V.V. 2005. The butterflies of Kyrgyzstan. KyivBrno: Tshikolovets Publications. 511 p.

Поступила в редакцию 1.9 .2021 